\title{
PERBEDAAN pH SALIVA MENYIKAT GIGI SEBELUM DAN SESUDAH MENGKONSUMSI MAKANAN MANIS PADA SISWA KELAS 7 SMP NEGERI 05 TUMINTING KOTA MADYA MANADO
}

\author{
I Ketut Harapan, ${ }^{1}$, Anneke A. Tahulending ${ }^{2}$, Shinta Ivana Andolo ${ }^{3}$ \\ 1,2,3) Jurusan Keperawatan Gigi Poltekkes Kemenkes ManadoJl.RW Mongisidi Malalayang II \\ Manado \\ Email : iketutharapan@gmail.com
}

\begin{abstract}
ABSTRAK
Latara Belakang : Saliva merupakan cairan tidak berwarna didalam rongga mulut yang dihasilkan oleh kelenjar saliva.Saliva mempunyai peran sebagai kapasitas buffer sehingga dapat mengatur naik turunnya $\mathrm{pH}$ saliva. Beberapa faktor yang menyebabkan terjadinya perubahan pada $\mathrm{pH}$ saliva antara lain rata-rata kecepatan aliran saliva, mikroorganisme rongga mulut, dan kapasitas buffer saliva. Tujuan : Untuk mengetahui perbedaan $\mathrm{pH}$ saliva menyikat gigi sebelum dan sesudah mengkonsumsi makanan manis pada siswa SMP Negeri 05 Tuminting di Manado. Metode : Jenis penelitian ekperimen semu dengan rancangan One Group Pretest-Postest. Sampel yang digunakan yaitu 33 responden yang memiliki syarat sesuai kriteria inklusi, alat ukur yang digunakan yaitu saliva check buffer. Data yang diperoleh ditabulasi dan diuji menggunakan uji statistik Paired t-test. Waktu penelitian minggu pertama Juli 2018 dan tempat penelitian di SMP Negeri 05 Manado. Hasil : Hasil penelitian menunjukkan bahwa rata-rata $\mathrm{pH}$ saliva pada awal pemeriksaan sebelum mengkonsumsi makanan manis nilai Mean sebesar 7,5848, dan nilai rata-rata $\mathrm{pH}$ saliva sesudah mengkonsumsi makanan manis nilai Mean sebesar 5,4545 dengan nilai rata dengan standar deviasi 2.6231. Analisa data menunjukkan bahwa terdapat perbedaan yang signifikan dimana nilai $p=0.00<\alpha(0.05)$ dengan tingkat kemaknaan $95 \%$, nilai $t_{\text {hitungyaitu sebesar }}$ 38.883 dan $t_{\text {tabel }}$ yaitu sebesar 2.037, dimana $t_{\text {hitung }}$ lebih besar dari $t_{\text {tabel. }}$ Kesimpulan : Terdapat perbedaan $\mathrm{pH}$ saliva menyikat gigi sebelum dan sesudah mengkonsumsi makanan manis. Untuk itu bagi siswa-siswi diharapkan rajin menjaga kesehatan gigi dengan mengurangi mengkonsumsi makanan yang mengandung gula.
\end{abstract}

Kata Kunci: pH Saliva, Menyikat gigi, Makanan Manis

\section{ABSTRACT}

Background: Saliva is a colorless liquid in the oral cavity produced by salivary glands. Saliva has a role as a buffer capacity so that it can regulate the rise and fall of salivary $\mathrm{pH}$. Some factors that cause changes in salivary $\mathrm{pH}$ include the average velocity of saliva, oral microorganisms, and salivary buffer capacity. Objective: To determine the difference in salivary $\mathrm{pH}$ of brushing teeth before and after consuming sweet foods in students of 05 Tuminting Public Middle School in Manado. Method: Type of quasi-experimental research with the design of the Pretest-Posttest One Group. The sample used was 33 respondents who had the conditions according to the inclusion criteria, the measuring instrument used was the saliva check buffer. The data obtained was tabulated and tested using the Paired t-test statistical test. Time of research for the first week of July 2018 and the place of research in SMP Negeri 05 Manado. Results: The results showed that the average salivary $\mathrm{pH}$ at the beginning of the examination before consuming sweet food Mean value of 7.5848, and the 
average value of salivary $\mathrm{pH}$ after consuming sweet foods Mean value of 5.4545 with an average value with standard deviation 2.6231. Data analysis shows that there are significant differences where the value of $\mathrm{p}=0.00<\alpha(0.05)$ with a significance level of $95 \%$, the value of tcount is 38.883 and table is equal to 2.037, where tcount is greater than $\mathrm{t}$ table. Conclusion: There are differences in salivary $\mathrm{pH}$ brushing teeth before and after consuming sweet foods. For this reason, students are expected to diligently maintain dental health by reducing consumption of foods containing sugar.

Keywords: Saliva pH, Brushing, Sweet Food

\section{PENDAHULUAN}

Untuk mewujudkan derajat kesehatan yang setinggi-tingginya bagi masyarakat, diselenggarakan upaya kesehatan yang terpadu dan menyeluruh dalam bentuk upaya kesehatan perseorangan dan upaya kesehatan masyarakat.Upaya kesehatan diselenggarakan dalam bentuk kegiatan dengan pendekatan promotif, preventif, kuratif, dan rehabilitatif yang diselenggarakan secara terpadu, menyeluruh, dan berkesinambungan. ${ }^{1}$

Kesehatan gigi dan mulut masih merupakan hal yang perlu diperhatikan, hal ini terlihat bahwa 90\% penduduk Indonesia menderita penyakit gigi dan mulut, adapun karies gigi merupakan masalah utamanya. Hasil Riset Kesehatan Dasar 2013 menunjukkan bahwa 25,9 persen penduduk Indonesia mempunyai masalah gigi dan mulut dalam 12 bulan terakhir. Terdapat 31,1 persen yang menerima perawatan dan pengobatan dari tenaga medis gigi (perawat gigi, dokter gigi atau dokter gigi spesialis), sementara 68,9 persen lainnya tidak dilakukan perawatan. ${ }^{2}$

Menyikat gigi merupakan tindakan preventif yang paling mudah dan murah dilakukan.Walaupun kegiatan pembersihan gigi secara mekanik ini dipandang mudah tetapi selama ini hasil yang maksimal sukar didapat, baik dari aspek kebersihan gigi dan faktor kerusakan lainnya. Pada umumnya anak sangat menyukai makanan manis khususnya cokelat, permen, dan kue-kue manis, tapisangat disayangkan kesadaran anak untuk selalu menjaga kebersihan mulut masih kurang memahami dengan baik sehingga karies gigi banyak dijumpai pada anak usia sekolah. ${ }^{8}$

Berdasarkan hasil penelitian Hidayat(2014), didapat bahwa terdapat perbedaan $\mathrm{pH}$ saliva menggosok gigi sebelum dan sesudah mengkonsumsi makanan manis dan lengket pada anak usia 10-12 tahun di SDN Melayu 2 Banjarmasin. ${ }^{3}$ Penelitian yang serupa juga dilakukan oleh Rahmawati (2014), menyatakan bahwa ada perbedaan $\mathrm{pH}$ saliva antara sebelum dan sesudah mengkonsumsi minuman ringan yang mengandung aspartam pada siswa kelas II dan kelas III Madrasah Ibtidaiyah Zam-Zam Zailani Banjarbaru Kalimantan Selatan Tahun 2014. ${ }^{4}$

Beberapa faktor yang menyebabkan terjadinya perubahan pada $\mathrm{pH}$ saliva antara lain rata-rata kecepatan aliran saliva, mikroorganisme rongga mulut, dan kapasitas buffer saliva. Selain itu ada faktorfaktor yang mempengaruhi pembentukan asam, antara lain: jenis karbohidrat yang terdapat dalam diet, konsentrasi karbohidrat dalam diet, jenis dan jumlah bakteri di dalam plak, keadaan fisiologis bakteri tersebut dan $\mathrm{pH}$ di dalam plak. Makanan manis dan lengket mengandung karbohidrat yang merupakan sumber energi utama bagi bakteri mulut dan secara langsung terlibat dalam penurunan $\mathrm{pH}$. Jenis karbohidrat yang paling cocok bagi produksi asam oleh bakteri di dalam plak adalah gula-gula sederhana, seperti sukrosa, glukosa, fruktosa, maltosa, dan lain-lain. Gula-gula ini mempunyai molekul yang kecil sehingga mudah berdifusi ke dalam plak dan dengan cepat akan dipecah oleh bakteri menjadi asam. ${ }^{3}$ Makanan karbohidrat, akan terjadi 
fermentasi terhadap glukosa makanan. Hasilnya berupa senyawa bersifat asam dan membuat lingkungan sekitar gigi bersuasana asam, dan dalam beberapa menit derajat keasaman akan meningkat atau $\mathrm{pH}$-nya turun. Bila berlanjut, penurunan nilai $\mathrm{pH}$ akan sampai ke nilai $\mathrm{pH}$ kritis, yaitu nilai $\mathrm{pH}$ yang dapat memicu dekalsifikasi (hilangnya garam kalsium) pada email gigi. Keberadaan perubahan suasana $\mathrm{pH}$ setelah makan ini akan kembali normal setelah 20-30 menit kemudian. Makanan manis dan lengket dapat berpengaruh terhadap terjadinya karies pada gigi anak-anak. Makanan manis dan lengket yang digunakan pada penelitian ini adalah cokelat, karena termasuk jenis makanan manis dan lengket serta lebih lunak dibandingkan dengan permen, biscuit, roti, dan wafer. 5

Hasil survei awal yang dilakukan pada tanggal 03 Mei 2018 pada Siswa SMP Negeri 05 Manado yang berjumlah 10 orang ditemukan masalah kesehatan gigi dan mulut khususnya karies gigi. Dari hasil pemeriksaan yang dilakukan pada siswa diperoleh nilai rata-rata DMF-T yaitu 3,4 termasuk kategori sedang yang ditetapkan oleh Oral Health Surveys yaitu 2,7-4,4. Hasil wawancara tentang cara memelihara kesehatan gigi dan mulut di dapat 4 orang yang mempunyai kebiasaan menyikat gigi $2 \mathrm{x}$ sehari, dan 6 orang menyikat gigi $1 \mathrm{x}$ sehari dan hanya pada waktu mandi saja.

Penelitian ini bertujuan untuk mengetahui perbedaaan $\mathrm{pH}$ saliva menyikat gigi sebelum dan sesudah mengkonsumsi makanan manis pada siswa kelas 7 SMP Negeri 05 Tuminting di Manado. Penelitian ini diharapkan dapat memberikan masukan dan bermanfaat bagi perkembangan ilmu pengetahuan kesehatan di bidang kesehatan gigi dan mulut yang berkaitan dengan Perbedaan $\mathrm{pH}$ Saliva Menyikat Gigi Sebelum dan Sesudah Mengkonsumsi Makanan Manis.

\section{METODE PENELITIAN}

Jenis penelitian yang digunakan dalam penelitian ini yaitu penelitian eksperimen semu dengan rancangan One Group PretestPostest yang tidak ada kelompok pembanding (kontrol) (Notoatmodjo, 2010). Bentuk Rancangan One Group Pretest And Posttest Design

\begin{tabular}{ccc} 
Pretest & Perlakuan & Post Test \\
\hline 01 & $\mathrm{X}$ & 02 \\
\hline
\end{tabular}

Variabel bebas (Independen Variabel) Makanan manis dan Menyikat gigi, Variabel terikat (Dependen Variabel) pH Saliva.

\section{Definisi Operasional}

1. Makanan manis adalah makanan yang disukai dari berbagai kalangan baik anakanak maupun orang dewasa. Rasa manis pada makanan ini bersumber dari gula yaitu sukrosa (gula tebu), adalah gabungan dua macam gula yaitu glukosa dan fruktosa, terdapat berbagai bentuk putih dan cokelat. Makanan manis yang digunakan dalam penelitian ini yaitu jenis cokelat batang yang dibeli di supermarket.

2. Menyikat gigi adalah tindakan yang menjadi rutinitas kita sehari-hari untuk membersihkan gigi dan mulut. Menyikat dan membersihkan gigi sebaiknya dilakukan minimal 2 kali sehari yaitu pada pagi hari dan sebelum tidur malam, tujuannya untuk mengangkat sisa-sisa makanan yang menempel dipermukaan ataupun disela-sela gigi dan gusi.

3. $\mathrm{pH}$ saliva adalah suatu derajat keasaman saliva yang diukur dengan satuan $\mathrm{pH}$ dan menggunakan alat ukur yaitu saliva check buffer.pHsaliva berada pada kriteria "baik" apabila pada salivacheck buffer berwarna hijau (nilai diantara 6,8-7,8), kriteria "sedang" apabila pada salivacheck biffer berwarna kuning (nilai diantara 6,0-6,6), kriteria "buruk" apabila pada saliva check buffer berwarna merah (nilai diantara 5,0-5,8). Skala yang digunakan yaitu skala interval. 


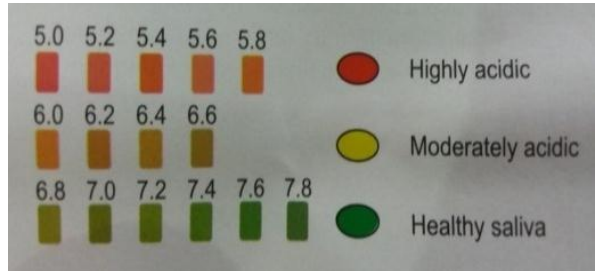

Gambar 1.pH Testing Chart

Populasi dalam penelitian ini yaitu seluruh siswa kelas $7^{3} \mathrm{SMP}$ Negeri 05 Tuminting di Manado dengan jumlah 37 orang. Sampel yang digunakan yaitu dengan teknik pengambilan sampel adalah total populasi dengan jumlah 37 orang. Dengan kriteria inklusi. Alat dan bahan dalam penelitian : diagnosa set (kaca mulut, sonde, pinset, dan excavator), saliva check buffer (alat ukur $\mathrm{pH}$ saliva), alat tulis (buku dan pena). Bahan, tempat saliva (wadah), cokelat, sikat gigi, pasta gigi, air mineral, masker, hand scoen,format penilaian $\mathrm{pH}$ saliva dan informed consent.

Data dianalisa dengan menggunakan uji Paired t-test. Variabel yang dianalisa yaitu perbedaan $\mathrm{pH}$ saliva menyikat gigi sebelum dan sesudah mengkonsumsi makanan manis. Untuk mengetahui perbedaan $\mathrm{pH}$ saliva menyikat gigi sebelum mengkonsumsi makanan manis dengan sesudah mengkonsumsi makanan manis digunakan uji statistic Paired t-test dengan perangkat lunak SPSS (Statistical Product and Service Solutions).

\section{HASIL}

\section{Gambaran Umum Lokasi Penelitian}

Sekolah Menengah Pertama Negeri 05 Manado merupakan salah satu sekolah menengah pertama yang ada di Manado bertempat di Jln. Hassanuddin No. 94 Manado, Tuminting dan dipimpin oleh ibu Mientje Adelina Watuseke. Sekolah ini telah menggunakan K-13 dalam pembelajaran. Guru yang mengajar di SMP Negeri 05 Manado berjumlah 38 orang dan siswa yang bersekolah di SMP Negeri 05 Manado berjumlah 863 orang yang terdiri dari siswa laki-laki berjumlah 422 orang dan siswa perempuan berjumlah 441 orang. Luas SMP Negeri 05 Manado adalah $2.400 \mathrm{~m}^{2}$. Sekolah ini memilki 20 ruang kelas, 3 ruang laboratorium, 1 ruang perpustakaan dan 2 ruang sanitasi siswa.

1.Distribusi Responden Berdasarkan Jenis dilihat pada tabel 1 di bawah ini :

Tabel 1. Distribusi Responden Berdasarkan Jenis kelamin

\begin{tabular}{ccc}
\hline $\begin{array}{c}\text { Jenis } \\
\text { Kelamin }\end{array}$ & Jumlah (n) & $\begin{array}{c}\text { Persentase } \\
(\%)\end{array}$ \\
\hline Laki-laki & 11 & 33.33 \\
Perempuan & 22 & 66.67 \\
\hline Total & 33 & 100 \\
\hline
\end{tabular}

Tabel 1 di atas menunjukkan bahwa distribusi responden menurut jenis kelamin, paling banyak ditemukan yaitu jenis kelamin perempuan sebanyak 22 responden (66.67\%).

2.Distribusi Kriteria Responden Berdasarkan pH Saliva Menyikat Gigi Sebelum Mengkonsumsi Makanan Manis, dapat dilihat pada tabel 2 di bawah ini :

Tabel 2. Distribusi Kriteria Responden berdasarkan pH Saliva Menyikat Gigi Sebelum Mengkonsumsi Makanan Manis.

\begin{tabular}{ccc}
\hline Kriteria & Jumlah $(\mathrm{n})$ & Persentase $(\%)$ \\
\hline Baik & 33 & 100 \\
Sedang & 0 & 0 \\
Buruk & 0 & 0 \\
\hline Total & 33 & 100 \\
\hline
\end{tabular}


Berdasarkan data pada tabel 2 di atas menunjukkan bahwa distribusi kriteria responden paling banyak adalah baik sebanyak 33 responden (100\%).

\section{Distribusi Kriteria Responden Berdasarkan pH Saliva Sesudah Mengkonsumsi Makanan Manis}

Tabel 3. Distribusi Kriteria Responden pH Saliva Sesudah Mengkonsumsi Makanan manis

\begin{tabular}{ccc}
\hline Kriteria & Jumlah (n) & $\begin{array}{c}\text { Persentase } \\
(\%)\end{array}$ \\
\hline Baik & 0 & 0 \\
Sedang & 4 & 12.12 \\
Buruk & 29 & 87.88 \\
\hline Total & 33 & 100 \\
\hline
\end{tabular}

Berdasarkan tabel 3 menunjukkan bahwa distribusi kriteria responden paling banyak adalah buruk sebanyak 29 responden (87.88\%), katagori sedang 4 orang $(12,12 \%)$ dan kriteria baik 0 responden ( $0 \%)$.

4. Analisis Perbedaan pH Saliva Menyikat Gigi Sebelum dan Sesudah Mengkonsumsi Makanan Manis.

Analisis perbedaan $\mathrm{pH}$ saliva menyikat gigi sebelum dan sesudah mengkonsumsi makanan manis dengan menggunakan uji paired t-test dengan tingkat kemaknaan 95\% $(\alpha=0,05)$ dapat dilihat pada tabel 4 di bawah ini :

Tabel 4. Distribusi Perbedaan pH Saliva Menyikat Gigi Sebelum dan Sesudah Mengkonsumsi Makanan Manis

\begin{tabular}{clcccc}
\hline \multicolumn{1}{c}{ Variabel } & Mean & SD & T & $\boldsymbol{P}$ \\
\hline $\mathrm{pH}$ & Menyikat gigi sebelum & & & & \\
Saliva & $\begin{array}{l}\text { mengkonsumsi makanan } \\
\text { Sebelum }\end{array}$ & 7.5848 & 1.9545 & & \\
manis & $\begin{array}{l}\text { Sesudah mengkonsumsi } \\
\text { Saliva }\end{array}$ & 5.4545 & 2.6231 & 38.883 & 0.000 \\
mesuanan manis & & & & &
\end{tabular}

Hasil analisis perbedaan $\mathrm{pH}$ saliva menyikat gigi sebelum dan sesudah mengkonsumsi makanan manis pada siswa kelas 7 SMP Negeri 05 Tuminting di Manado diperoleh nilai rata-rata $\mathrm{pH}$ saliva menyikat gigi sebelum mengkonsumsi makanan manis yaitu 7.5848 dengan standar deviasi (SD) 1.9545 sedangkan $\mathrm{pH}$ saliva sesudah mengkonsumsi makanan manis diperoleh nilai rata-rata yaitu 5.4545 dengan standar deviasi (SD) 2.6231 .

Analisa data menunjukkan hasil yang signifikan dimana nilai $p 0.00<\alpha(0.05)$, sedangkan nilai $t_{\text {hitung }}$ yaitu sebesar 38.883 dan $t_{\text {tabel }}$ yaitu sebesar 2.037, dimana $t_{\text {hitung }}$ lebih besar dari $t_{\text {tabel. }}$ Hasil tersebut menunjukkan bahwa terdapat perbedaan yang signifikan rata-rata antara $\mathrm{pH}$ saliva responden menyikat gigi sebelum mengkonsumsi makanan manis dengan sesudah mengkonsumsi makanan manis.

\section{Pembahasan}

Kesehatan merupakan investasi untuk menunjang kualitas kehidupan yang lebih baik, termasuk didalamnya peningkatan pemeliharaan dibidang kesehatan gigi dan mulut. ${ }^{7}$ Kesehatan gigi dan mulut penting bagi kesehatan dan kesejahteraan tubuh secara umum dan sangat memengaruhi kualitas kehidupan, termasuk fungsi bicara, dan pengunyahan. Gangguan kesehatan mulut akan berdampak pada kinerja seseorang. ${ }^{8}$

Hasil distribusi menurut kriteria responden berdasarkan $\mathrm{pH}$ saliva menyikat gigi sebelum mengkonsumsi makanan 
manis pada tabel 3 terdapat kriteria responden baik yaitu sebanyak 33 responden $(100 \%)$. Hal ini menunjukkan bahwa responden yang berkategori baik lebih banyak dikarenakan didalam pasta gigi mengandung komponen flour sehingga dapat meningkatkan sekresi saliva dan juga dapat menaikkan $\mathrm{pH}$ saliva sehingga dapat meningkatkan terjadinya remineralisasi email dan mencegah terjadinya karies. Kegiatan menyikat gigi adalah tindakan preventif yang paling mudah dan murah dilakukan, tujuannya adalah untuk mencegah terjadinya penyakit pada jaringan keras maupun jaringan lunak dengan menghilangkan plak dan membersihkan gigi dan mulut dari sisa makanan dan debris. Dalam pasta gigi terkandung bahan-bahan abrasif, pembersih, bahan penambah rasa dan warna, serta pemanis. ${ }^{3}$

Hasil distribusi menurut kriteria responden berdasarkan $\mathrm{pH}$ saliva sesudah mengkonsumsi makanan manis pada tabel 4 terdapat kriteria responden terbanyak yaitu buruk dengan jumlah 29 responden $(87.88 \%)$ sedangkan kriteria sedang berjumlah 4 responden (12.12\%). Pada makanan manis kandungan gula sangat tinggi, sehingga dapat menyebabkan penurunan $\mathrm{pH}$ dan cenderung ini akan menjadi sumber energi utama bagi bakteri di dalam mulut dan dengan cepat akan dipecah oleh bakteri menjadi asam dan lama-kelamaan akan menyebabkan demineralisasi email sehingga terjadinya karies gigi. Rahmawati (2014), menyatakan bahwa mekanisme penurunan $\mathrm{pH}$ saliva terjadi setelah makan sesuatu yang mengandung gula terutama adalah sukrosa.Bakteri menggunakan fruktosa dalam suatu metabolisme glikolosis untuk memperoleh energi. Hasil akhir dari glikolosis ini adalah asam laktat yang akan menciptakan kadar keasaman yang ekstra untuk menurunkan $\mathrm{pH}$ saliva. ${ }^{4}$

Pada nilai rata-rata $\mathrm{pH}$ saliva responden menyikat gigi sebelum mengkonsumsi makanan manis sebesar 7.5848 dan nilai rata-rata $\mathrm{pH}$ saliva sesudah mengkonsumsi makanan manis sebesar 5.4545. Hal ini menunjukkan bahwa nilai rata-rata (mean) yaitu 2.1313, sehingga ada perbedaan antara $\mathrm{pH}$ saliva menyikat gigi sebelum dan sesudah mengkonsumsi makanan manis pada siswa kelas 7 SMP Negeri 05 Tuminting di Manado.

Berdasarkan hasil analisa Paired Sample t-test pada tingkat kemaknaan $95 \%$ $(\alpha=0,05)$ diperoleh nilai $p=0.00(p<0.05)$ hasil menunjukkan ada perbedaan signifikan antara $\mathrm{pH}$ saliva menyikat gigi sebelum dan sesudah mengkonsumsi makanan manis. Mengkonsumsi makanan manis dianjurkan untuk menyikat gigi, tetapi bila tidak sempat untuk menyikat gigi sebaiknya untuk kumur-kumur dengan air agar keasaman $\mathrm{pH}$ saliva di dalam mulut itu kembali normal dan tidak berisiko terjadinya karies gigi. Faktor yang menyebabkan terjadinya perubahan pada $\mathrm{pH}$ saliva antara lain rata-rata kecepatan aliran saliva, mikroorganisme rongga mulut, dan kapasitas buffer saliva. Selain itu ada faktor-faktor yang mempengaruhi pembentukan asam, antara lain jenis karbohidrat yang terdapat dalam diet, konsentrasi karbohidrat dalam diet, jenis dan jumlah bakteri di dalam plak, keadaan fisiologis bakteri tersebut dan $\mathrm{pH}$ di dalam plak. $^{3}$

Penelitian ini sejalan dengan hasil penelitian dari Hidayat (2014) bahwa terdapat perbedaan yang bermakna antara $\mathrm{pH}$ saliva menggosok gigi sebelum dan sesudah mengkonsumsi makanan manis dan lengket pada menit ke-5, 15, dan 30 yang diukur menggunakan $\mathrm{pH}$ meter pada anak usia 10-12 tahun di SDN Melayu 2 Banjarmasin. ${ }^{9}$

\section{KESIMPULAN DAN SARAN}

\section{Kesimpulan}

Kesimpulan dalam penelitian ini bahwa terdapat perbedaan $\mathrm{pH}$ saliva yang signifikan dengan tingkat kemaknaan $95 \%$ $(\alpha=0,05)$ dan diperoleh nilai $\mathrm{p}=0,00<$ $\mathrm{p}=0,005$ antara menyikat gigi sebelum 
mengkonsumsi makanan manis dengan sesudah mengkonsumsi makanan manis.

\section{Saran}

Setelah melaksanakan penelitian dan membahas hasil penelitian ini, peneliti dapat memberikan saran :

1. Kepada seluruh siswa SMP Negeri 05 Tuminting di Manado diharapkan agar dapat menjaga kesehatan gigi dan mulut dengan cara rajin menyikat gigi 2 kali sehari yaitu pagi sesudah sarapan dan malam sebelum tidur. Selain itu rutin memeriksakan gigi ke dokter gigi setiap 6 bulan sekali atau 1 tahun 2 kali, memperbanyak makan buah-buahan yang berserat dan berair, dan kurangi memakan makanan yang manis dan lengket. Jika disaat jam sekolah tidak sempat menyikat gigi dianjurkan untuk berkumur-kumur dengan air setelah selesai makan makanan manis agar makanan tidak menempel pada sela-sela gigi.

2. Sebagai bahan referensi dan hasil penelitian dapat digunakan sebagai dasar atau acuan dalam melaksanakan penelitian selanjutnya serta dapat digunakan sebagai pedoman dalam pembuatan Karya Tulis Ilmiah.

\section{DAFTAR PUSTAKA}

1. Undang-Undang Dasar Negara Republik Indonesia Nomor 36 Tahun 2009 Tentang Kesehatan.

2. Riskesdas, (2013).Badan Penelitian dan Pengembangan Kesehatan Kementerian Kesehatan RI. Jakarta.
3. Hidayat, R. (2016). Kesehatan Gigi \& Mulut Apa Yang Sebaiknya Anda Tahu?.Yogyakarta.

4. Rahmawati, I., Said, F., \& Hidayati, S. (2014). Perbedaan pH Saliva Antara Sebelum dan Sesudah Mengkonsumsi Minuman Ringan.Jurnal Skala kesehatan.6 (1:23-26).

5. Suyuti, M. (2010).Pengaruh Makanan Serba Manis dan Lengket Terhadap Terjadinya Karies Gigi.Makassar

6. Suratri, M.A.L., Jovina, T.A., \& Tjahja, I.N. (2017).Pengaruh (pH) Saliva Terhadap Terjadinya Karies Gigi Pada Anak Usia Prasekolah. Jurnal Penelitian Kesehatan. 45 (4:247).

7. Sariningsih, E. (2012). Merawat Gigi Anak Sejak Usia Dini. Jakarta: Gramedia

8. Putri, M.H., Herijulianti, E., \& Nurjannah, N. (2012).Ilmu Pencegahan Penyakit Jaringan Keras dan Jaringan Pendukung Gigi.EGC: Jakarta.

9. Hidayat, S., Adhani, R., \& Arya, I.W. (2014).Perbedaan pH Saliva Menggosok Gigi Sebelum dan Sesudah Mengkonsumsi Makanan Manis dan Lengket.Jurnal Kedokteran Gigi. II (1:39-44).

Putri, M.H., Herijulianti, E., \& Nurjannah, N. (2012).Ilmu Pencegahan Penyakit Jaringan Keras dan Jaringan Pendukung Gigi.EGC: Jakarta. 